Article

\title{
Rural Districts between Urbanization and Land Abandonment: Undermining Long-Term Changes in Mediterranean Landscapes
}

\author{
Ilaria Zambon ${ }^{1}{ }^{(0)}$, Agostino Ferrara ${ }^{2}$ (), ${ }^{\text {, Rosanna Salvia }}{ }^{3}$, Enrico Maria Mosconi ${ }^{4}{ }^{(0)}$, Luigi Fici ${ }^{4}$, \\ Rosario Turco ${ }^{5}$ and Luca Salvati ${ }^{5, *}$ \\ 1 Department of Agricultural and Forestry Sciences (DAFNE), Tuscia University, Via San Camillo de Lellis, \\ I-01100 Viterbo, Italy; ilaria.zambon@unitus.it \\ 2 School of Agricultural, Forest, Food and Environmental Sciences, University of Basilicata, Via dell'Ateneo \\ Lucano 10, I-85100 Potenza, Italy; agostino.ferrara@unibas.it \\ 3 MEDES, Foundation for Sustainable Development of the Mediterranean, C/da San Licandro 1, \\ Sicignano degli Alburni, I-84029 Salerno, Italy; rosanna@medes.eu \\ 4 Department of Economics, Engineering, Society and Business Organization, Tuscia University, \\ Via del Paradiso 47, I-01100 Viterbo, Italy; enrico.mosconi@unitus.it (E.M.M.); fici@unitus.it (L.F.) \\ 5 Council of Agricultural Research and Economics (CREA), Viale S. Margherita 80, I-52100 Arezzo, Italy; \\ rosario.turco@crea.gov.it \\ * Correspondence: luca.salvati@crea.gov.it; Tel.: +39-0575-353-021
}

Received: 20 March 2018; Accepted: 11 April 2018; Published: 12 April 2018

\begin{abstract}
The present study investigates changes in the rural landscapes of a Mediterranean country (Greece) over a long time period (1970-2015) encompassing economic expansions and recessions. Using a spatial distribution of 5 basic agricultural land-use classes (arable land, garden crop, vineyards, tree crop and fallow land) derived from official statistics at 6 years (1970, 1979, $1988,1997,2006,2015)$, a quantitative analysis based on correlation and multivariate techniques was carried out to identify recent changes in the Greek agricultural landscape at prefectural level during different economic waves. Empirical results evidenced both intuitive and counter-intuitive landscape transformations, including: (i) a progressive, spatially-homogeneous reduction of cropland; (ii) a (more or less) rapid decrease in the surface of high-input crops, including arable land, horticulture and vineyards; (iii) a parallel increase in the surface of tree crops, especially olive; (iv) a spatially-heterogeneous decrease of fallow land concentrated in metropolitan and tourism districts, especially in the last decade; and, finally, (v) increasingly diversified landscapes in rural, accessible areas close to the sea coast. Based on a correlation analysis with background socioeconomic indicators, our findings reflect the multiple impacts of urbanization and land abandonment on the composition and diversity of rural landscapes. Changes in agricultural land-use were moulded by multiple drivers depending on latent transformations in rural systems and inherent conflicts with expanding urban regions. Together with market conditions and the Common Agricultural Policy subsidy regime, social contexts and the economic cycle are important when identifying long-term changes in agricultural landscapes, especially in transitional socio-ecological systems.
\end{abstract}

Keywords: land-use changes; fallow land; indicators; multivariate analysis; Greece

\section{Introduction}

Especially in peri-urban areas, land-use changes were promoted by multiple factors revealing controversial aspects at the base of socioeconomic processes [1-4] and leading to new hybrid landscapes, altering the traditional relationship between urban and rural areas [5]. After World War 
II, a period of intense urbanization began in Europe, with low-quality land, for example, abandoned fields, pastures, sparse cropland and bare land surrounding large cities, converted to urban use [6-9]. In more recent decades, urbanization has involved an increasing amount of high-quality rural land, with dispersed urbanization having major implications for peri-urban landscape structure, quality and diversity [10-15].

Driving forces of landscape transformation were deeply investigated in earlier contributions [16-20]. Changing rural land-use, traditional cropping systems and long-established agronomic practices towards intensive and specialized food productions and high-density livestock along the urban-rural gradient has demonstrated to determine a process of "landscape homologation," owing to the simultaneous action of ecological and socioeconomic factors [21-27]. In both developed and emerging countries, rural landscapes are increasingly experiencing standardized development models leading to more fragmented and economically-fragile landscape structures, poor ecological quality, increased habitat fragmentation and soil degradation [28-32], mixing together relict semi-natural areas and scattered low-density settlements in a confused and indistinct matrix [12,13,33-35].

Understanding long-term, latent relationships among land-use, socioeconomic constraints and environmental factors is indispensable to clarify the inherent complexity of landscape transformations although, often due to low quality or partial lack of digital data, the influencing drivers remain frequently unknown [36-38]. Preventing landscape changes toward urbanization under specific socioeconomic dynamics, requires monitoring tools and planning solutions for sustainable development of peri-urban areas [39-41]. Developing conceptual and explanatory frameworks founded on empirical case studies is necessary to inform a sustainable land management strategy [42-44]. Investigation of landscape transformations in rural areas may also benefit from a comprehensive analysis of agronomic practices and use of cultivated land in terms of intensification or extensification of cropping systems [45,46]. In this regard, fallow land expansion or contraction over time represent an interesting proxy of rural landscape transformation [47-51]. Fallow land dynamics may reflect (i) seasonal movements of livestock and mixed farming, (ii) real-estate speculation and (iii) land abandonment [34,37,52-54].

Fallow land is one of the agricultural soil covers featured by fluctuating and dynamic developments due to exogenous and contextual influences if compared with other uses (e.g., forests) which maintain a more stable and less complex development [55]. Spatio-temporal variability in the surface area of fallow land may indicate the multifaceted impact of environmental agricultural and socioeconomic factors [37]. By comparing metropolitan and rural districts, the present work hypothesized that fluctuations in fallow land surface area are associated with economic cycles, urban-rural relationships, different models of rural development, types and density of cultivation, cropping systems (extensive or intensive, with varying degree of mechanization), production inputs and the related agricultural income [56]. The 2007 crisis in Mediterranean countries and especially in Greece, has determined socioeconomic conditions leading to a progressive re-colonization of rural land after decades of abandonment or sub-optimal use for cropping. In addition, thanks to sustainable development issues [57], relevance has been given to the matter of circular economy, outlining the role of fallow land as a stock of land for intensification (or extensification) of cropping systems at landscape scale [31,58-60].

Based on these premises, the present study investigates agricultural land-use changes in Greece during a long-time span (1970-2015), using spatial analysis, non-parametric correlation and multivariate statistical techniques. The main purpose is to identify (and discuss the role of) multiple drivers of latent modifications in socioeconomic local systems, based on inherent conflicts with expanding urban regions. The approach proposed in this study was aimed at verifying if landscape composition, structure and diversity significantly changed along the urban gradient during the investigated time period. Intuitive and counter-intuitive transformations in the agricultural landscape of Greece included: (i) a spatially-homogeneous and continuous decrease of cropland; (ii) decreasing surface areas (e.g., arable land, horticulture and vineyards); (iii) a parallel growth of tree crops, especially olive; (iv) a spatially-heterogeneous decrease of fallow land concentrated in metropolitan and tourism districts, especially in the last decade of economic crisis; and (v) an 
increasingly diversified landscape in accessible areas with intermediate population density and close to the sea coast. The novelty of the proposed approach lies in a comprehensive analysis of different landscape processes in rural districts based on an exploratory framework investigating the intimate relationships with the economic cycle over a sufficiently long time period to encompass sequential expansion and recession waves.

\section{Materials and Methods}

\subsection{Study Area}

The study area focuses on Greece $\left(301,330 \mathrm{~km}^{2}\right)$, a European country with a divided urban system centred on Athens, the capital city and Salonika [61]. Major urban centres include Patras in the Peloponnese and Iraklion in Crete [62]. Approximately 80\% of Greek land is composed of mountains and upland. The larger lowlands are placed in the prefectures of Thessaly and Central Macedonia, which are key areas devoted to large-scale, high-input agriculture. Greece constitutes the most southern continental part of the Balkan peninsula embraced by the Peloponnese peninsula, the Aegean and Ionian Seas, separated by the Corinth Channel. The country includes more than 1500 islands in the Aegean and Ionian Seas. The most important islands are Crete, the Cyclades and the Ionian Islands [63].

Following Eurostat census, Greek arable land consisted mainly of cereals (29\%), where fallow lands are only $4.3 \%$. The latter recorded significant increases (over than $60 \%$ ) in the last decade (2000-2010), even if the overall agricultural landscape of Greece has extensively modified over time [54]. This framework also brings out regional disparities in both socioeconomic and environmental domains, characterizing a thoughtful difficulty to face a truly shared sustainable development $[64,65]$. Innovation in cultivation and mechanization systems have advanced significantly the agricultural sector since the 1970s [66]. However, several factors (e.g., limited job opportunities in rural areas determining massive emigration towards urban centres) limited the progress of Greek rural society [24]. Furthermore, a limited specialization in high-input agriculture reveals important endogenous and exogenous driving forces, for example, poorly accessible areas (e.g., islands) and climatic impacts (e.g., droughts) $[24,52,63,67]$. In some Greek zones, a gradual decline of practices that combined diverse rural land-uses (e.g., fallow land), were used as olives and grazelands for the growing livestock, decreasing land-use diversity [54]. The simplification of local multifunctional land-use systems to intensive livestock grazing changed ecosystem equilibrium towards environmental, soil, vegetation and biodiversity degradation processes [68-73]. In fact, Greece is one of the European countries suffering from soil erosion and desertification, loss of organic matter, salinization and soil compaction [74-76], with about $20 \%$ of its land surface exposed to erosion risk [77,78].

Agriculture plays an important factor role in the local economy in the Peloponnese peninsula, while industry has developed in the northern region, such as Central Macedonia [79] and close to the metropolitan area of Athens. Whereas on the eastern plain, Thessaly is known for intensive agriculture and manufacturing (although slightly declining since the 1980). As one of the Mediterranean Islands, Crete has established an economy based mainly on agriculture and tourism $[62,80]$.

\subsection{Statistical Data and Indicators}

In the present study, prefectures were defined as the elementary spatial unit since administrative boundaries have been largely used in both quantitative exercises and qualitative case studies dealing with urban geography and landscape analysis [34,43]. Based on the spatial distribution of 5 basic agricultural land-use classes (arable land, garden crop, vineyards, tree crop and fallow land) at 6 years (1970, 1979, 1988, 1997, 2006 and 2015), a quantitative analysis based on correlation and multivariate techniques was proposed to recognize recent agricultural changes in the Greek landscape. From this set of variables, derived from Agriculture statistics of Greece at prefectural level, useful indicators were provided to understand changes in the Greek agricultural landscape [64]. The spatial distribution of percent share of land by each land-use class and year was mapped by ArcGIS software (ESRI Inc., 
Redwoods, CA, USA) using prefectural boundaries as spatial unit. To assess rural changes, fallow farmland has been already used as indicator of rural development in earlier works [81-83]. The term 'fallow' defines agronomic practices aimed at securing sustainability of cropping systems leaving land uncultivated for one (or more) annual cycle(s). Fallow systems are traditional management practices aimed at re-establishing soil fertility, protecting rural areas from aridity, low soil fertility and productivity, reducing risk of erosion $[81,84]$. Establishing provisional patches, fallow land compensates habitat loss and mitigates persistent effects of agricultural intensification [85]. Fallow lands are traditionally involved in agronomic schemes based on the principle of crop rotation [84], getting nutrient for the forthcoming cropping season [86].

\subsection{Data Analysis}

A summary analysis of agricultural land-use change in Greece was developed using a Principal Component Analysis (PCA). The latter was performed on the data matrix composed by 51 prefectures and the percent land surface classified at 5 basic agricultural land-use classes in the investigated years. As the PCA was based on the correlation matrix, the number of significant factors was chosen by retaining the components with eigenvalue $>1$. Based on the scores of the most important factors, prefectures were mapped into different groups. Entities (agricultural land-use classes and provinces) placed close each other in the factorial plane indicate spatial convergence $[33,87]$.

Focusing on agricultural land-use change and relative landscape diversification during the investigated time period, pair-wise relationships between contextual variables and agricultural land-use in Greece were explored using non-parametric Spearman rank correlation analysis testing for significant correlations at $p<0.05$ after Bonferroni's correction for multiple comparisons. The contextual variables include (i) per-capita income; (ii) population density; (iii) distance from Athens; (iv) distance from Salonika; (v) distance from the sea coast; and (vi) a dummy indicating tourism districts. Percent share of garden crop in total agricultural area and two additional dummies (presence of international airport and public university) were not correlated with any other variable and were not considered further.

A Spearman rank correlation was also applied between Pielou J evenness index of landscape diversification and the abovementioned contextual variables during the studied period (1970-2015), illustrating agricultural landscape diversification in Greece [88]. Pielou's index defines the evenness degree of landscape diversification, indirectly assessing stability (or change) of agricultural systems during a long-time span (1970-2015). The absolute value of a diversity index increases both when the number of classes increases and when evenness increases. For a given number of classes, the value of a diversity index is maximized when all classes are equally abundant. Being derived from the Shannon index, Pielou's index was applied to the composition of the landscape found in each prefecture according to the following formula:

$$
\mathrm{J}=\mathrm{H}^{\prime} / \mathrm{H}_{\max }
$$

where $\mathrm{H}_{\max }$ is the natural logarithm of the number of considered classes $(n=7)$. Although Shannon index ranges from 0 (the lowest diversity) to infinity (the highest diversity), Pielou's J index ranges between 0 (the lowest evenness) and 1 (the highest evenness).

\section{Results}

\subsection{Agricultural Land-Use Changes in GREECE (1970-2015)}

The predominant agricultural land-use class in Greece can be associated with crops on arable land, recording the highest scores $(>50 \%)$ in the whole study period, 1970-2015 (Table 1). However, the analysis of percent share of land by land-use class pointed out relevant changes for the Greek agriculture, especially for arable land. Even though the latter cover the largest agricultural area in Greece, arable land declined continuously from 1979 (61.9\%) to 2015 (52.9\%). Vineyards also decreased moderately over time (from $5.4 \%$ in 1979 to $2.9 \%$ in 2015). Gardens have undergone a moderate 
increase over time, however, in the last year of survey (2015) their percent share of land decreased slightly. Areas under trees (e.g., compact plantations, including olive trees) were the only land-use class increasing continuously over time (from $16.6 \%$ in 1979 to $31.0 \%$ in 2015).

Table 1. Agricultural changes in Greece, 1970-2015 (percent share of land by land-use class).

\begin{tabular}{cccccc}
\hline Year & $\begin{array}{c}\text { Crops on } \\
\text { Arable Land }\end{array}$ & Garden Area & $\begin{array}{c}\text { Vines (Grapes } \\
\text { and Raisins) }\end{array}$ & $\begin{array}{c}\text { Areas under Trees } \\
\text { (Compact Plantations) }\end{array}$ & Fallow Land \\
\hline 1970 & 61.9 & 2.6 & 5.4 & 16.6 & 13.4 \\
1979 & 60.0 & 2.8 & 4.8 & 19.6 & 12.8 \\
1988 & 59.0 & 2.8 & 4.1 & 22.3 & 11.8 \\
1997 & 57.6 & 3.1 & 3.4 & 24.4 & 11.5 \\
2006 & 55.3 & 3.0 & 3.4 & 26.9 & 11.4 \\
2015 & 52.9 & 2.1 & 2.9 & 31.0 & 11.2 \\
\hline
\end{tabular}

Spatial dynamics occurred in the last 45 years in Greece were finally investigated considering the percent share of fallow land in total agricultural land (Figure 1). The highest percentages $(>20 \%)$ are evident in cropping systems featuring intensive agriculture and crop rotation. Since 1979, especially in Attica and Peloponnese, fallow land was concentrated in relatively few prefectures. In the central-northern region, fallow land showed a more homogeneous distribution, associated to the most intensive cultivation models (e.g., garden crops) and viticulture. However, an increased incidence of fallow land has occurred in recent years in this area, especially around Salonika. In the southern part of Greece, fallow land has also experienced an intense decline since 1988, leading to a sharp reduction in its area in the following years and thus reaching values less than 10\%. For example, landscape modifications in Cyclades indicated a progressive abandonment of marginal agricultural systems and a rather similar trend was observed in Corinth area.
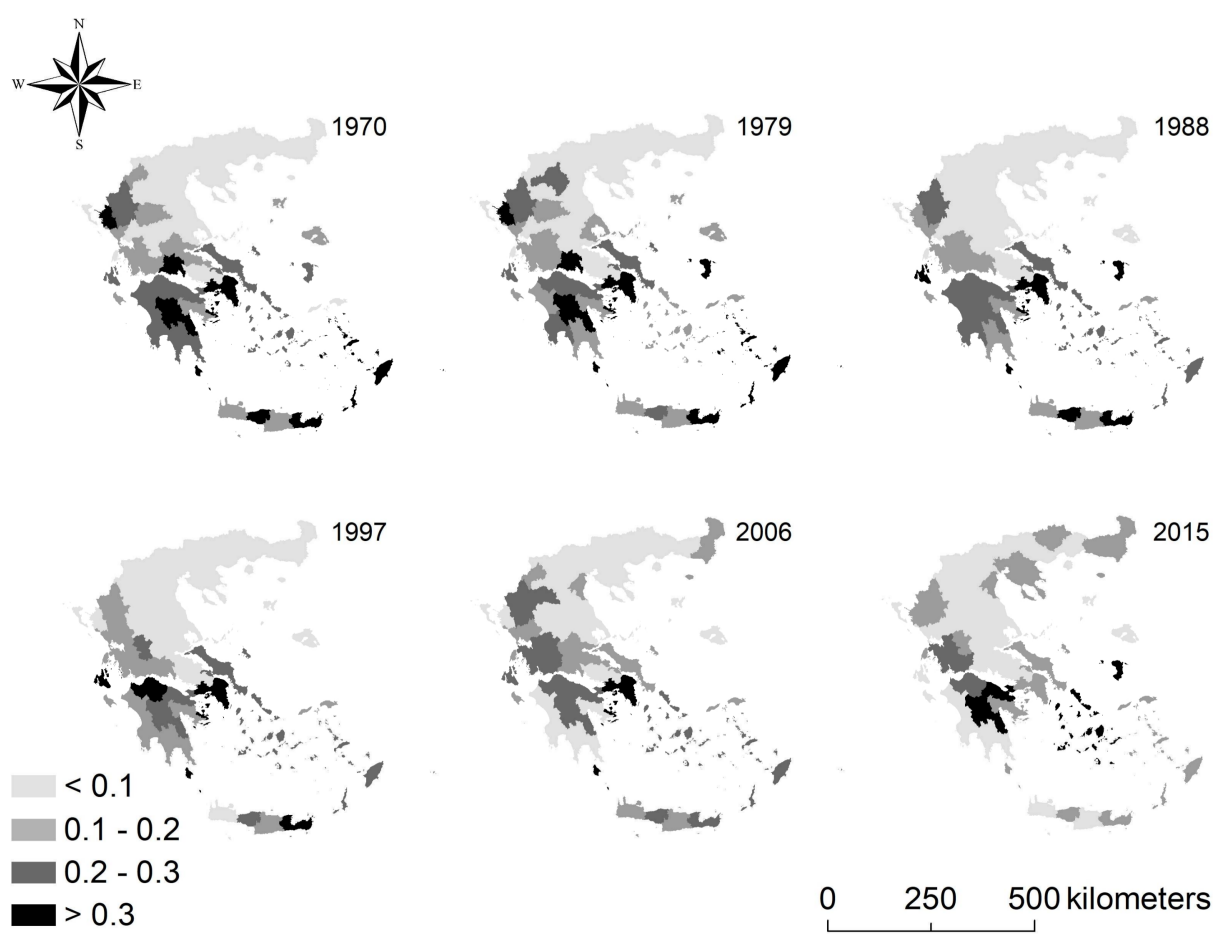

Figure 1. Percent share of fallow land in total agricultural land in Greece, 1970-2015. 


\subsection{Landscape Evaluation Using Principal Component Analysis}

The PCA extracted three factors cumulating $85 \%$ of total variance (Table 2). The most important factor (explaining $47.2 \%$ of total variance) defined the Greek prefectures which base their economic production on tree crops and vineyards from 1979 to 1997, opposed to districts specialized in arable crops. PC1 was positively associated to fallow land until 1997, as well as to largely extensive cultivation systems. Fallow land was typically associated to a landscape with extensively managed cropping systems and heterogeneous structure.

Table 2. Loadings $(>|0.6|)$ of Principal Component Analysis investigating agricultural land-use in Greece.

\begin{tabular}{|c|c|c|c|c|c|c|c|}
\hline Variable & PC1 & PC2 & PC3 & Variable & PC1 & PC2 & PC3 \\
\hline Ara70 & -0.98 & & & Tre70 & 0.80 & & \\
\hline Ara79 & -0.98 & & & Tre79 & 0.84 & & \\
\hline Ara88 & -0.99 & & & Tre88 & 0.85 & & \\
\hline Ara97 & -0.99 & & & Tre97 & 0.86 & & \\
\hline Ara06 & -0.98 & & & Tre06 & 0.85 & & \\
\hline Ara15 & -0.95 & & & Tre15 & 0.85 & & \\
\hline Cro70 & & 0.95 & & Vin70 & & & \\
\hline Cro79 & & 0.95 & & Vin79 & 0.67 & & 0.63 \\
\hline Cro88 & & 0.96 & & Vin88 & 0.68 & & 0.64 \\
\hline Cro97 & & 0.95 & & Vin97 & 0.63 & & 0.69 \\
\hline Cro06 & & 0.96 & & Vin06 & & & 0.71 \\
\hline Cro15 & & 0.85 & & Vin15 & & & 0.71 \\
\hline Fal70 & 0.64 & & & & & & \\
\hline Fal79 & 0.66 & & & & & & \\
\hline Fal88 & 0.72 & & & & & & \\
\hline Fal97 & 0.68 & & & & & & \\
\hline Fal06 & & 0.62 & & & & & \\
\hline Fal15 & & 0.61 & & & & & \\
\hline Expl. Var. \% & 47.2 & 24.1 & 13.4 & & & & \\
\hline
\end{tabular}

PC2 (explaining 24.1\% of total variance) revealed local districts specialized in agricultural productions. Fallow areas were positively associated with this axis in recent years (2006-2015), indicating consolidation of extensive cropping systems. Fallow land resulted to be relatively more common where there is more land available for agriculture; in prefectures with a more intensive cultivation system, the proportion of fallow land in total land area was significantly smaller. Component 3 (explaining 13.4\% of total variance) identified areas specialized on vine production, possibly correlated with specific external factors.

Scores of principal components on agricultural land-use change in Greece were illustrated in Figure 2. The first quadrant identifies agricultural areas designed for viticulture and olive trees (e.g., Kerkyra and Zakynthos). In these areas, rural landscapes were relatively fragmented, diversified and heterogeneous, with a moderately low proportion of fallow land. Prefectures classified in the fourth quadrant showed a large extension of fallow land, possibly associated with traditional pastoral uses of land. A restricted agricultural specialization in these areas may derive from other factors, such as poor accessibility, climate aridity or even urbanization. 

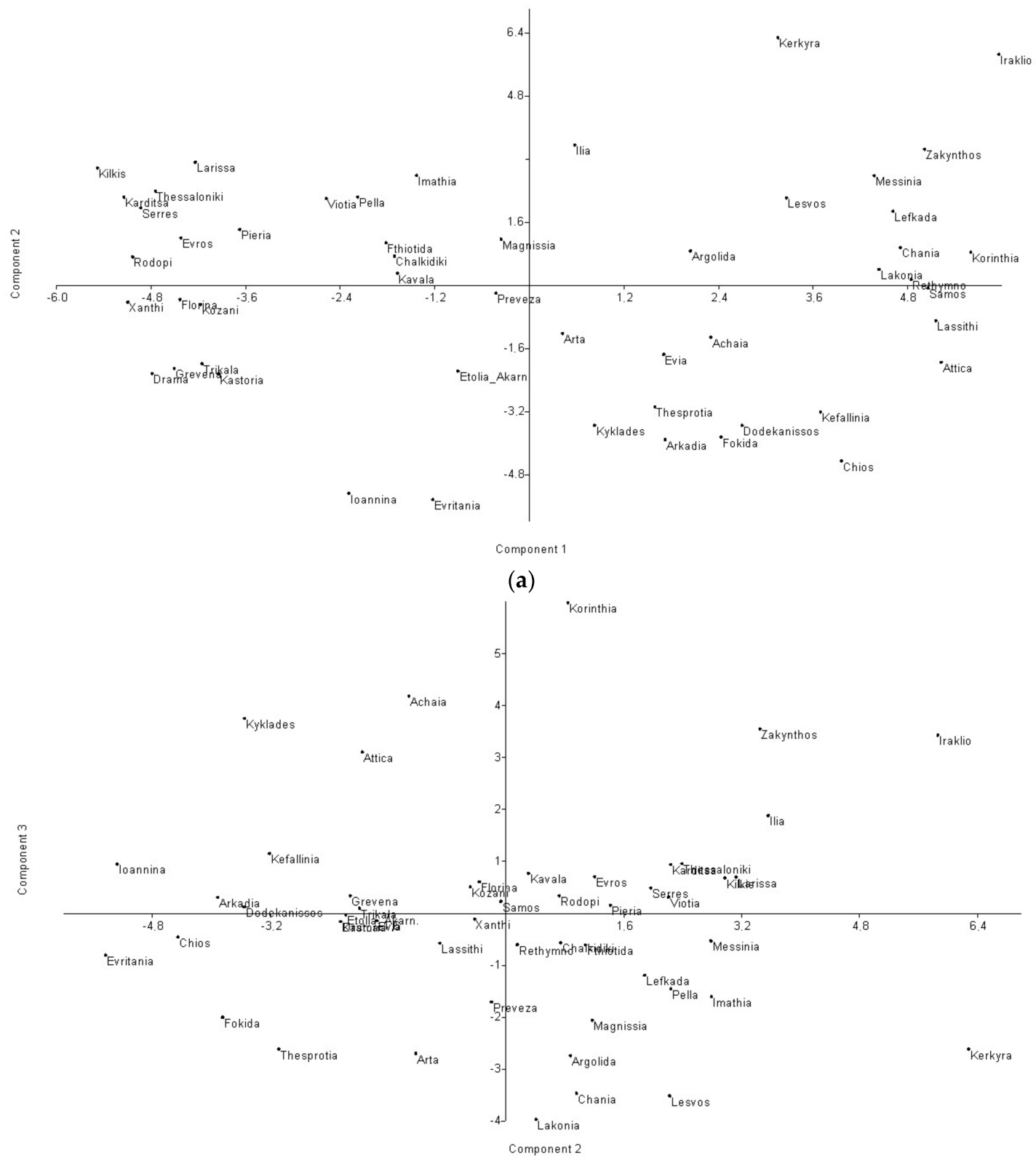

(b)

Figure 2. Scores of principal components illustrating changes in agricultural land-use in Greece (a) PC1 vs. PC2, (b) PC2 vs. PC3.

The socioeconomic contexts on the left side of Figure 2 highlighted prefectures with both annual and tree crops, distinguishing the most intensive systems (second quadrant) as in northeast Greece (e.g., Larisa and Salonika), from less intensive ones (third quadrant) recognizing more disadvantaged and less accessible socioeconomic contexts towards the Ionic Sea (e.g., Evritania and Ioannina). The latter areas are located far from the coast, revealing a widespread traditional agricultural system dominated by less intensive annual cultivation than other areas.

The scores of the first three principal components on agricultural land-use change in Greece were shown in Figure 3. Axis 1 outlines a latitudinal gradient, distinguishing northern and southern regions of Greece. In northern areas, agricultural land-uses were homogenously distributed, contrasting southern areas, hosting fragmented and heterogeneous landscapes possibly reflecting a greater diversification and biodiversity. In this regard, PC1 identified a territorial structure composed of 
different degree of soil fertility and climatic conditions. Axis 2 divided Greece into eastern and western districts. Areas bordering the Aegean Sea displayed a marked agricultural specialization, opposed with the Ionian side, including areas less devoted to agriculture.
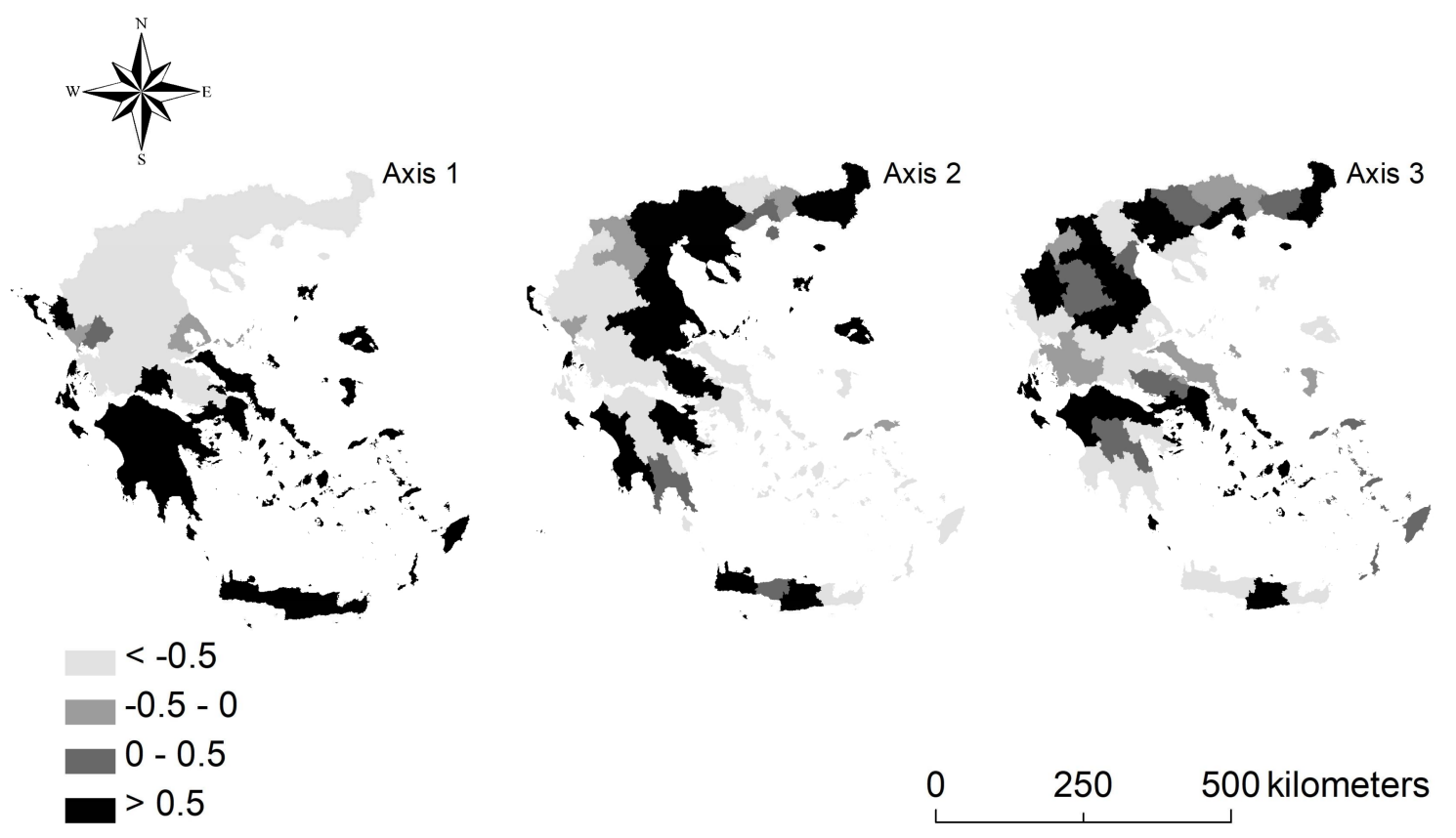

Figure 3. Scores of the selected components illustrating changes in agricultural land-use in Greece (Axis 1) PC1, (Axis 2) PC2, (Axis 3) PC3.

Axis 3 expressed a typical urban-rural gradient in Greece. Urban and compact areas diverged from rural prefectures since they are more accessible and connected by infrastructural networks. In this group, Athens and its region (Attica) emerged together with Crete, Macedonia and Salonika, followed by medium-density urban regions, for example, Larisa, Volos and Ioannina; finally, mixed urban-rural areas such as Achaia (Patras) can be identified.

\subsection{Pair-Wise Spearman Rank Correlations}

Pair-wise Spearman rank correlation analysis between contextual variables and agricultural land-use was applied to explore spatial changes in Greece during the investigated time period (Table 3), considering the following variables: (i) per-capita income; (ii) population density; (iii) distance from Athens; (iv) distance from Salonika; (v) distance from the sea coast; and (vi) tourism district.

Results of correlation analysis indicate that wealth regions are devoted to viticulture, resulting in high income in primary sector. Regions devoted to arable crops, often leading to more intensive agricultural systems, showed a coherent specialization in industrial productions and are located in the central and northern part of Greece. Compared with other non-urban districts, agricultural areas showed a relatively high population density, suggesting that rural areas in Greece are defined by settlement models with intermediate population density. This complex system declined progressively along the rural-urban gradient in the last decade. Agriculture became part of metropolitan contexts, mixing residential and productive settlements. 
Table 3. Spearman rank correlation between background context variables and agricultural land-use in Greece, $1970-2015$ *.

\begin{tabular}{|c|c|c|c|c|c|c|}
\hline Variable & $\begin{array}{l}\text { Per-Capita } \\
\text { Income }\end{array}$ & $\begin{array}{l}\text { Population } \\
\text { Density }\end{array}$ & $\begin{array}{c}\text { Distance from } \\
\text { Athens }\end{array}$ & $\begin{array}{c}\text { Distance from } \\
\text { Salonika }\end{array}$ & $\begin{array}{l}\text { Distance from } \\
\text { the Sea Coast }\end{array}$ & $\begin{array}{l}\text { Tourism } \\
\text { District }\end{array}$ \\
\hline Arable70 & -0.54 & & & -0.84 & -0.54 & -0.60 \\
\hline Arable79 & -0.52 & & & -0.80 & -0.52 & -0.59 \\
\hline Arable88 & -0.48 & & & -0.81 & -0.54 & -0.60 \\
\hline Arable97 & -0.45 & & & -0.79 & -0.56 & -0.57 \\
\hline Arable06 & & & & -0.79 & -0.54 & -0.58 \\
\hline Arable15 & & & & -0.79 & -0.51 & -0.57 \\
\hline Crops70 & & 0.52 & & & & \\
\hline Crops79 & & 0.50 & & & & \\
\hline Crops88 & & 0.51 & & & & \\
\hline Crops97 & & 0.50 & & & & \\
\hline Crops06 & & 0.50 & & & & \\
\hline \multicolumn{7}{|l|}{ Crops15 } \\
\hline Fallow70 & & & & 0.74 & & \\
\hline Fallow79 & & & & 0.69 & & \\
\hline Fallow88 & & & -0.46 & 0.77 & & \\
\hline Fallow97 & & & -0.47 & 0.72 & 0.46 & \\
\hline Fallow06 & & & & 0.53 & & \\
\hline \multicolumn{7}{|l|}{ Fallow15 } \\
\hline Trees70 & & & & 0.61 & 0.54 & 0.64 \\
\hline Trees79 & & & & 0.64 & 0.53 & 0.60 \\
\hline Trees88 & & & & 0.63 & 0.51 & 0.55 \\
\hline Trees97 & & & & 0.62 & 0.51 & 0.53 \\
\hline Trees06 & & & & 0.65 & 0.54 & 0.53 \\
\hline Trees15 & 0.58 & & & 0.54 & & \\
\hline Vines70 & 0.62 & & & 0.60 & & 0.44 \\
\hline Vines79 & 0.61 & & & 0.59 & & 0.51 \\
\hline Vines88 & 0.61 & & & 0.59 & & 0.49 \\
\hline Vines97 & 0.62 & & & 0.59 & & 0.49 \\
\hline Vines06 & 0.63 & & & 0.56 & & 0.49 \\
\hline Vines15 & & & & 0.63 & 0.49 & 0.51 \\
\hline
\end{tabular}

* Percent share of garden crop in total agricultural area and the two dummies "presence of an international airport" and "presence of a public university" were not correlated significantly with any other variable (significance tested at $p<0.05$ after Bonferroni's correction for multiple comparisons).

Three distance variables were calculated to better understand the relationship between urban and rural contexts. The first variable corresponded to the distance from Athens, the capital of Greece. Fallow (and abandoned) areas concentrated in Attica and, less intensively, in other metropolitan regions of Greece. Distance from Salonika, the second city in Greece was less correlated with the spatial distribution of fallow land; in this case, topographical and territorial factors justified a greater rural specialization. In fact, the neighbouring region of Macedonia was characterized by a strong presence of arable land. Fallow land, tree crop and vineyards are less common in Salonika region. Distance from coastal areas influenced primarily the spatial distribution of tree crops and vineyards (especially in the most recent period). Arable lands were mainly located far from the sea coast. A similar spatial pattern was observed for crops associated to tourism districts (tree crops and vineyards).

\subsection{Agricultural Land-Use, Fallow Land and Landscape Diversification}

Pielou J evenness index of landscape diversification was correlated with the selected contextual variables in Greece (Table 4). Agricultural landscapes were different depending on the existing crop. Rural landscapes resulted to be less varied when dominated by arable land $\left(r_{s}=-0.91\right.$ in 1979 and -0.67 in 2015). Landscapes dominated by vineyards, fallow land and tree crop systems were more diversified $\left(r_{s}>0.5\right)$. Heterogeneous landscapes in central and southern Greece were positively associated with per-capita income. The spatial distribution of Pielou J index was illustrated in Figure 4, confirming the findings presented above. The most heterogeneous areas coincide with 
Peloponnese, Attica and Crete. Especially in Crete, cropping systems were increasingly associated with discontinuous urbanization linked to the tourism sector and thus leading to a moderate decline of traditional agricultural landscapes.

Table 4. Spearman rank correlation between Pielou J evenness index of landscape diversification and selected background variables in Greece, 1970-2015*.

\begin{tabular}{ccccccc}
\hline Variable & $\mathbf{1 9 7 0}$ & $\mathbf{1 9 7 9}$ & $\mathbf{1 9 8 8}$ & $\mathbf{1 9 9 7}$ & $\mathbf{2 0 0 6}$ & $\mathbf{2 0 1 5}$ \\
\hline Arable land & -0.91 & -0.87 & -0.84 & -0.82 & -0.67 & \\
Vineyards & 0.69 & 0.68 & 0.68 & 0.72 & 0.63 & 0.49 \\
Tree crop & 0.74 & 0.70 & 0.68 & 0.67 & 0.51 & \\
Fallow land & 0.79 & 0.81 & 0.84 & 0.79 & 0.66 & 0.55 \\
Income per-capita & 0.56 & 0.58 & 0.53 & 0.53 & 0.48 & \\
Distance from Athens & -0.40 & -0.46 & -0.49 & -0.49 & -0.46 & -0.50 \\
Distance from Salonika & 0.82 & 0.77 & 0.74 & 0.74 & 0.61 & \\
Distance from the sea coast & 0.55 & 0.54 & 0.54 & 0.54 & 0.48 & \\
Tourism district & 0.53 & 0.48 & 0.45 & 0.45 & & \\
\hline
\end{tabular}

* Percent share of garden crop in total agricultural area, population density and the two dummies "presence of an international airport" and "presence of a public university" were not correlated significantly with Pielou evenness J index at every year of investigation (significance tested at $p<0.05$ after Bonferroni's correction for multiple comparisons).
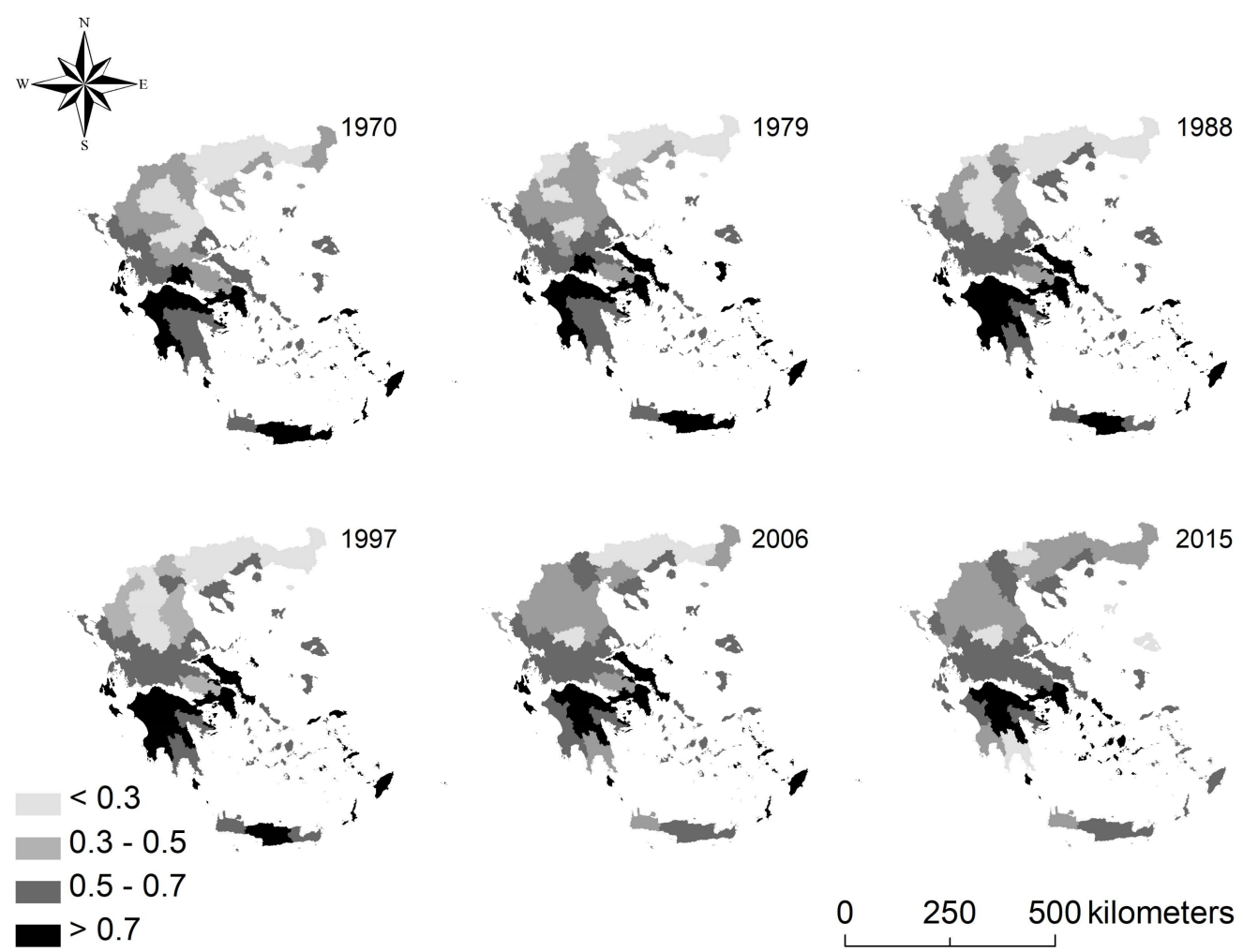

Figure 4. Spatial distribution of Pielou J evenness index illustrating agricultural landscape diversification in Greece, 1970-2015.

\section{Discussion}

Fallow land assumes the role of land stock for different functions: (i) crop rotation, seasonal use of land and mixed farming [54,67,84]; (ii) more intensive crops for high-value farming systems where fallow land can be considered as set-aside area [84,89]; (iii) pastoral purposes, fertilizing land and mitigate pervasive effects of agricultural intensification [85,86]; and (iv) abandonment of 
agricultural land, under prospective urban and tourism use [80,90-92]. Fallow land can positively impact biodiversity and agro-ecosystem quality, allowing a multifunctional land-use and income diversification [81]. Empirical findings of this study outlined that, where fallow land is less common, there are more homogeneous and poorly connected agricultural systems. With more land available for production, fallow land allows intensification of cropping systems. Concentration of fallow land around Athens also reveals a progressive abandonment of agricultural land for speculative purposes. In this regard, fallow land was concentrated in cropping systems of central and southern Greece, especially Attica and Peloponnese, in the first two decades of observation. In the northern area, fallow land displays a more homogeneous distribution, associated to intensive cultivation models and viticulture, which is an important source of income for farmers [79,81]. In fact, Mediterranean olive plantations and vineyards were not abandoned since they guarantee economically-viable products [93]. For instance, an increased incidence of fallow land has occurred in recent years in the northern area, especially around Salonika. By contrast, fallow land experienced an intense decline in the southern part of Greece since 1988. Among the Greek islands [63,80], the Cyclades underwent intense abandonment of agricultural systems in 2015, thanks to tourism pressure, together with the Corinth area. In the latter circumstance, this phenomenon can be also associated with infrastructural development leading to construction of the high-speed railroad linking Athens to Patras [94]. In this regard, fallow land can also be defined as land reservoir awaiting both cultivation and speculation linked to urbanization and infrastructure development $[90,91]$.

Our analysis revealed some inherent peculiarities of Greek rural areas. Despite a total reduction in agricultural land, there was a moderate growth of tree crops with mixed management (both intensive and extensive). For instance, Greece is one of the main producer of pistachios in Europe [95], mainly in marginal and remote areas [96], such as in Aegina island (Attica) [97]. In addition, an increasing wine specialization emerged in Greece due to the related exogenous factors (e.g., territorial, cultural and socioeconomic) enabling profitable income.

Our analysis finally indicates a substantial divergence in rural landscape composition before and after the most recent economic crisis. This can be justified by a progressive decline of CAP (Common Agricultural Policy) subsidies. From 1970 to 1997, the CAP-driven subsidy regime ensured stability of agricultural systems in Europe [24]. However, since the 1990s, the economic support of farm holders has substantially decreased, leading to important changes in the agricultural sector. Correspondingly, the Greek agricultural system has undergone effective structural and functional transformations in recent years, possibly reflected in structure and composition of rural landscapes [93]. In addition, agro-environmental EU regulations have allowed the awareness of more conservative agricultural models, possibly devoted to extensive cropping systems, for example, based on vineyards and olive groves. In the 2000s, the reduction of CAP subsidies led to a progressive restructuring of rural landscapes in Greece [98-100].

In addition to EU agricultural policy reform, the 2007 economic crisis has taken on a decisive and impacting role in Greek rural systems [64-91], accelerating land-use changes and transformations in primary productions. The wealthiest industrial regions in central and northern Greece were progressively shifting to viticulture, possibly resulting in a higher agricultural income. Landscape diversification has recently increased in northern Greece, being relatively stable in other areas such as Attica, Peloponnese and Crete [79]. For instance, peri-urban areas in Attica were increasingly composed of urban and rural elements preserving a large proportion of olive groves assuring a diversified landscape [14]. In other coastal regions, intensive cropping systems have sometimes stimulated urbanization processes, possibly leading to a less diversified landscape.

In summary, agricultural land-use transformations can be related to variability in fallow land use, reflecting joint action of multiple drivers: (i) geographical factors (elevation, latitude, accessibility, distance from the sea coast); (ii) incidence of CAP subsidies [92,101]; (iii) latent social transformations; (iv) evolution of the regional economic base, toward commerce, tourism and advanced services $[64,79,80]$. 
Evaluating the possible effects of different land-use alternatives on biodiversity is essential for guiding objective management choices [102-104]. The present study discovered landscape change paths in Greece and their possible impact on landscape diversity using spatial analysis and multivariate statistical models. Results pointed out the usefulness of comparative and multi-temporal approaches to landscape changes in complex regions [23,105-109].

Predicting the future of agricultural landscapes in Greece is relatively difficult due to the different driving forces involved [24]. Results of this study indicates that protection of a spatially-balanced landscape structure along the urban-rural gradient is a key target for strategies promoting environmental sustainability of Mediterranean regions. Future objectives of landscape conservation increasingly require appropriate strategies for sustainable development, containing urbanization-driven land speculation, soil sealing and land degradation $[4,84,110]$.

\section{Conclusions}

A shift from a spatially-balanced, structurally-complex and functionally-diversified agricultural landscape to more homogeneous systems defines a typical process of simplification and homologation typical of contemporary rural regions and reflecting a progressive decline in land-use diversification. These processes may impact ecosystem functioning and increase ecological fragility of relict cropping systems [110]. Using multi-temporal land-use statistics and high-resolution diachronic maps, further studies are essential to investigate the role of structural and functional transformations in rural landscapes as a response to increasing anthropogenic pressure and climate change impacts along urban-rural gradients [31]. In this regard, analysing the changing spatial configuration of landscapes, may provide a knowledge base supporting a sustainable management of traditional cropping systems aimed at reducing land abandonment and soil misuse, mixing together operational indications from geographical, socioeconomic and ecological perspectives [111-115]. A comprehensive analysis of changes over time in landscape composition focusing on specific land-use classes, such as fallow land, may contribute significantly to new prospective visions for sustainable development of rapidly-evolving rural districts. In this regard, integrating agricultural statistics, land-use variables and landscape diversity indexes with socioeconomic indicators assessing local contexts definitely provides suitable tools for a comprehensive assessment of landscape transformations advancing appropriate measures for both economically-dynamic districts and remote, economically-disadvantaged areas.

Author Contributions: The authors contributed equally to this work.

Conflicts of Interest: The authors declare no conflict of interest.

\section{References}

1. Aguilar, A.G. Peri-urbanization, illegal settlements and environmental impact in Mexico City. Cities 2008, 25, 133-145. [CrossRef]

2. Briassoulis, H. Policy-oriented integrated analysis of land-use change: An analysis of data needs. Environ. Manag. 2001, 27, 1-11. [CrossRef] [PubMed]

3. Jomaa, I.; Auda, Y.; Abi Saleh, B.; Hamzé, M.; Safi, S. Landscape spatial dynamics over 38 years under natural and anthropogenic pressures in Mount Lebanon. Landsc. Urban Plan. 2008, 87, 67-75. [CrossRef]

4. Couch, C.; Petschel-held, G.; Leontidou, L. Urban Sprawl in Europe: Landscapes, Land-Use Change and Policy; Blackwell: London, UK, 2007.

5. Antrop, M. Landscape change and the urbanization process in Europe. Landsc. Urban Plan. 2004, 67, 9-26. [CrossRef]

6. Carlucci, M.; Grigoriadis, E.; Rontos, K.; Salvati, L. Revisiting an Hegemonic Concept: Long-term 'Mediterranean Urbanization' in between city re-polarization and metropolitan decline. Appl. Spat. Anal. Policy 2017, 10, 347-362. [CrossRef]

7. Di Feliciantonio, C.; Salvati, L. 'Southern' alternatives of urban diffusion: Investigating settlement characteristics and socioeconomic patterns in three Mediterranean regions. Tijdschr. Econ. Soc. Geogr. 2015, 106, 453-470. [CrossRef] 
8. Portnov, B.A.; Safriel, U.N. Combating desertification in the Negev: Dryland agriculture vs. dryland urbanization. J. Arid Environ. 2004, 56, 659-680. [CrossRef]

9. Zambon, I.; Serra, P.; Sauri, D.; Carlucci, M.; Salvati, L. Beyond the 'Mediterranean City': Socioeconomic Disparities and Urban Sprawl in three Southern European Cities. Geogr. Ann. B 2017, 99, 319-337. [CrossRef]

10. Weber, C.; Petropoulou, C.; Hirsch, J. Urban development in the Athens metropolitan area using remote sensing data with supervised analysis and GIS. Int. J. Remote Sens. 2005, 26, 785-796. [CrossRef]

11. Weber, C.; Puissant, A. Urbanisation pressure and modeling of urban growth: Example of the Tunis Metropolitan Area. Remote Sens. Environ. 2003, 86, 341-352. [CrossRef]

12. Cakir, G.; Un, C.; Baskent, E.Z.; Kose, S.; Sivrikaya, F.; Keles, S. Evaluating urbanization, fragmentation and land-use/cover change pattern in Istanbul city, Turkey from 1971 to 2002. Land Degrad. Dev. 2008, 19, 663-675. [CrossRef]

13. Catalàn, B.; Sauri, D.; Serra, P. Urban sprawl in the Mediterranean? Patterns of growth and change in the Barcelona Metropolitan Region 1993-2000. Landsc. Urban Plan. 2008, 85, 174-184.

14. Moissidis, A.; Duquenne, M.N. Peri-Urban Rural Areas in Greece: The Case of Attica, 1997 European Society for Rural Sociology. Sociol. Rural. 1997, 37, 228-239. [CrossRef]

15. Nikolakopoulos, K.; Pavlopoulos, K.; Chalkias, C.; Manou, D. Monitoring the urban expansion of Athens using remote sensing and GIS techniques in the last 35 years. Proc. SPIE 2005, 5983, 64-75.

16. Burgi, M.; Hersperger, A.M.; Schneeberger, N. Driving forces of landscape change-Current and new directions. Landsc. Ecol. 2004, 19, 857-868. [CrossRef]

17. Bürgi, M.; Bieling, C.; Von Hackwitz, K.; Kizos, T.; Lieskovský, J.; Martín, M.G.; Printsmann, A. Processes and driving forces in changing cultural landscapes across Europe. Landsc. Ecol. 2017, 32, 2097-2112. [CrossRef]

18. Barbati, A.; Corona, P.; Salvati, L.; Gasparella, L. Natural forest expansion into suburban countryside: Gained ground for a green infrastructure? Urban For. Urban Green. 2013, 12, 36-43. [CrossRef]

19. Plieninger, T.; Draux, H.; Fagerholm, N.; Bieling, C.; Burgi, M.; Kizos, T.; Kuemmerle, T.; Primdahl, J.; Verburg, P.H. The driving forces of landscape change in Europe: A systematic review of the evidence. Land Use Policy 2016, 57, 204-214. [CrossRef]

20. Zambon, I.; Benedetti, A.; Ferrara, C.; Salvati, L. Soil Matters? A Multivariate Analysis of Socioeconomic Constraints to Urban Expansion in Mediterranean Europe. Ecol. Econ. 2018, 146, 173-183. [CrossRef]

21. Polyzos, S.; Christopoulou, O.; Minetos, D.; Leal Filho, W. An overview of urban-rural land-use interactions in Greece. Int. J. Agric. Resour. Gov. Ecol. 2008, 7, 276-296. [CrossRef]

22. Schneider, A.; Woodcock, C.E. Compact, dispersed, fragmented, extensive? A comparison of urban growth in twenty-five global cities using remotely sensed data, pattern metrics and census information. Urban Stud. 2008, 45, 659-692. [CrossRef]

23. Marull, J.; Pino, J.; Tello, E.; Cordobilla, M.J. Social metabolism, landscape change and land-use planning in the Barcelona Metropolitan Region. Land Use Policy 2009, 27, 497-510. [CrossRef]

24. Kizos, T.; Vlahos, G. The Evolution of the Agricultural Landscape. Reclaiming the Greek Landscape; Med-INA: Athens, Greece, 2012; pp. 133-143.

25. Ribeiro, P.F.; Santos, J.L.; Santana, J.; Reino, L.; Leitão, P.J.; Beja, P.; Moreira, F. Landscape makers and landscape takers: Links between farming systems and landscape patterns along an intensification gradient. Landsc. Ecol. 2016, 31, 791-803. [CrossRef]

26. Santana, J.; Reino, L.; Stoate, C.; Moreira, F.; Ribeiro, P.F.; Santos, J.L.; Rotenberry, J.T.; Beja, P. Combined effects of landscape composition and heterogeneity on farmland avian diversity. Ecol. Evol. 2017, 7, 1212-1223. [CrossRef] [PubMed]

27. Salvati, L.; Sabbi, A. Exploring long-term land cover changes in an urban region of southern Europe. Int. J. Sustain. Dev. World Ecol. 2011, 18, 273-282. [CrossRef]

28. Ferretti, M.; Marchetto, A.; Arisci, S.; Bussotti, F.; Calderisi, M.; Carnicelli, S.; Cecchini, G.; Fabbio, G.; Bertini, G.; Matteucci, G.; et al. On the tracks of Nitrogen deposition effects on temperate forests at their southern European range-An observational study from Italy. Glob. Chang. Biol. 2014, 20, 3423-3438. [CrossRef] [PubMed]

29. Frondoni, R.; Mollo, B.; Capotorti, G. A landscape analysis of land cover change in the Municipality of Rome (Italy): Spatio-temporal characteristics and ecological implications of land cover transitions from 1954 to 2001. Landsc. Urban Plan. 2011, 100, 117-128. [CrossRef] 
30. Sarvestani, M.S.; Latif Ibrahim, A.; Kanaroglou, P. Three decades of urban growth in the city of Shiraz, Iran: A remote sensing and geographical information systems application. Cities 2011, 28, 320-329. [CrossRef]

31. Serra, P.; Vera, A.; Tulla, A.F.; Salvati, L. Beyond urban-rural dichotomy: Exploring socioeconomic and land-use processes of change in Spain (1991-2011). Appl. Geogr. 2014, 55, 71-81. [CrossRef]

32. Shrestha, M.K.; York, A.M.; Boone, C.G.; Zhang, S. Land fragmentation due to rapid urbanization in the Phoenix Metropolitan Area: Analyzing the spatiotemporal patterns and drivers. Appl. Geogr. 2012, 32, 522-531. [CrossRef]

33. Ferrara, A.; Salvati, L.; Sateriano, A.; Carlucci, M.; Gitas, I.; Biasi, R. Unraveling the 'stable' landscape: A multi-factor analysis of unchanged agricultural and forest land (1987-2007) in a rapidly-expanding urban region. Urban Ecosyst. 2016, 19, 835-848. [CrossRef]

34. Salvati, L.; Gargiulo, V.; Rontos, K.; Sabbi, A. Latent Exurban Development: City Expansion along the Rural-To-Urban Gradient in Growing and Declining Regions of Southern Europe. Urban Geogr. 2013, 34, 376-394. [CrossRef]

35. Ceccarelli, T.; Bajocco, S.; Luigi Perini, L.; Luca Salvati, L. Urbanisation and land take of high quality agricultural soils-exploring long-term land use changes and land capability in Northern Italy. Int. J. Environ. Res. 2014, 8, 181-192.

36. Colantoni, A.; Grigoriadis, E.; Sateriano, A.; Sarantakou, E.; Salvati, L. Back to Von Thunen: A Southern European perspective on mono-centric urban growth, economic structure and non-urban land decline. Int. Plan. Stud. 2017, 22, 173-188. [CrossRef]

37. Hietel, E.; Waldhardt, R.; Otte, A. Linking socio-economic factors, environment and land cover in the German Highlands, 1945-1999. J. Environ. Manag. 2005, 75, 133-143. [CrossRef]

38. Marcucci, D.J. Landscape history as a planning tool. Landsc. Urban Plan. 2000, 49, 67-81. [CrossRef]

39. Bruegmann, R. Sprawl: A Compact History; University of Chicago Press: Chicago, IL, USA, 2005.

40. Kazemzadeh-Zow, A.; Zanganeh Shahraki, S.; Salvati, L.; Neisani Samani, N. A Spatial Zoning Approach to Calibrate and Validate Urban Growth Models. Int. J. Geogr. Inf. Sci. 2017, 31, 763-782. [CrossRef]

41. Pili, S.; Grigoriadis, E.; Carlucci, M.; Clemente, M.; Salvati, L. Towards Sustainable Growth? A Multi-criteria Assessment of (Changing) Urban Forms. Ecol. Indic. 2017, 76, 71-80. [CrossRef]

42. Ferrara, C.; Carlucci, M.; Grigoriadis, S.; Corona, P.; Salvati, L. A comprehensive insight into the geography of forest cover in Italy: Exploring the importance of socioeconomic local contexts. For. Policy Econ. 2017, 75, 12-22. [CrossRef]

43. Munafò, M.; Salvati, L.; Zitti, M. Estimating soil sealing at country scale-Italy as a case study. Ecol. Indic. 2013, 26, 36-43. [CrossRef]

44. Colantoni, A.; Grigoriadis, E.; Sateriano, A.; Venanzoni, G.; Salvati, L. Cities as selective land predators? A Lesson on Urban Growth, (Un) effective planning and Sprawl Containment. Sci. Total Environ. 2016, 545-546, 329-339. [CrossRef] [PubMed]

45. Delfanti, L.; Colantoni, A.; Recanatesi, F.; Bencardino, M.; Sateriano, A.; Salvati, L. Solar plants, environmental degradation and local socioeconomic contexts: A case study in a Mediterranean country. Environ. Assess. Impact Rev. 2016, 61, 88-93. [CrossRef]

46. Kosmas, C.; Karamesouti, M.; Kounalaki, K.; Detsis, V.; Vassiliou, P.; Salvati, L. Land degradation and long-term changes in agro-pastoral systems: An empirical analysis of ecological resilience in Asteroussia-Crete (Greece). Catena 2016, 147, 196-204. [CrossRef]

47. Kuemmerle, T.; Erb, K.; Meyfroidt, P.; Müller, D.; Verburg, P.H.; Estel, S.; Haberl, H.; Hostert, P.; Jepsen, M.R.; Kastner, T.; et al. Challenges and opportunities in mapping land use intensity globally. Curr. Opin. Environ. Sustain. 2013, 5, 484-493. [CrossRef] [PubMed]

48. Li, L.; Friedl, M.A.; Xin, Q.; Gray, J.; Pan, Y.; Frolking, S. Mapping crop cycles in China using MODIS-EVI time series. Remote Sens. 2014, 6, 2473-2493. [CrossRef]

49. Estel, S.; Kuemmerle, T.; Levers, C.; Baumann, M.; Hostert, P. Mapping cropland-use intensity across Europe using MODIS NDVI time series. Environ. Res. Lett. 2016, 11, 024015. [CrossRef]

50. Portmann, F.T.; Siebert, S.; Döll, P. MIRCA2000—global monthly irrigated and rainfed crop areas around the year 2000: A new high-resolution data set for agricultural and hydrological modeling. Glob. Biogeochem. Cycles 2010, 24, GB1011. [CrossRef]

51. Siebert, S.; Portmann, F.T.; Döll, P. Global patterns of cropland use intensity. Remote Sens. 2010, 2, $1625-1643$. [CrossRef] 
52. Kizos, T.; Koulouri, M. Agricultural landscape dynamics in the Mediterranean: Lesvos (Greece) case study using evidence from the last three centuries. Environ. Sci. Policy 2006, 9, 330-342. [CrossRef]

53. Plieninger, T.; Schaich, H.; Kizos, T. Land-use legacies in the forest structure of silvopastoral oak woodlands in the Eastern Mediterranean. Reg. Environ. Chang. 2011, 11, 603-615. [CrossRef]

54. Van der Sluis, T.; Kizos, T.; Pedroli, B. Landscape change in Mediterranean farmlands: Impacts of land abandonment on cultivation terraces in Portofino (Italy) and Lesvos (Greece). J. Landsc. Ecol. 2014, 7, $23-44$.

55. Mertens, B.; Lambin, E.F. Land-cover-change trajectories in southern Cameroon. Ann. Assoc. Am. Geogr. 2000, 90, 467-494. [CrossRef]

56. Recanatesi, F.; Clemente, M.; Grigoriadis, S.; Ranalli, F.; Zitti, M.; Salvati, L. A fifty-years sustainability assessment of Italian Agro-forest Districts. Sustainability 2016, 8, 32. [CrossRef]

57. Biasi, R.; Brunori, E.; Smiraglia, D.; Salvati, L. Linking traditional tree-crop landscapes and agro-biodiversity in Central Italy using a database of typical and traditional products: A multiple risk assessment through a data mining analysis. Biodivers. Conserv. 2015, 24, 3009-3031. [CrossRef]

58. Ferrara, A.; Salvati, L.; Sabbi, A.; Colantoni, A. Urbanization, Soil Quality and Rural Areas: Towards a Spatial Mismatch? Sci. Total Environ. 2014, 478, 116-122. [CrossRef] [PubMed]

59. Smiraglia, D.; Ceccarelli, T.; Bajocco, S.; Perini, L.; Salvati, L. Unraveling Landscape Complexity: Land Use/Land Cover Changes and Landscape Pattern Dynamics (1954-2008) in Contrasting Peri-Urban and Agro-Forest Regions of Northern Italy. Environ. Manag. 2015, 56, 916-932. [CrossRef] [PubMed]

60. Tomao, A.; Quatrini, V.; Corona, P.; Ferrara, A.; Lafortezza, R.; Salvati, L. Resilient landscapes in Mediterranean urban areas: Understanding factors influencing forest trends. Environ. Res. 2017, 156, 1-9. [CrossRef] [PubMed]

61. Gemenetzi, G. Thessaloniki: The changing geography of the city and the role of spatial planning. Cities 2017, 64, 88-97. [CrossRef]

62. Ioannides, Y.M.; Petrakos, G. Regional disparities in Greece: The performance of Crete, Peloponnese and Thessaly. EIB Pap. 2000, 5, 30-58.

63. Tzanopoulos, J.; Vogiatzakis, I.N. Processes and patterns of landscape change on a small Aegean island: The case of Sifnos, Greece. Landsc. Urban Plan. 2011, 99, 58-64. [CrossRef]

64. Cecchini, M.; Zambon, I.; Pontrandolfi, A.; Turco, R.; Colantoni, A.; Mavrakis, A.; Salvati, L. Urban spraw1 and the 'olive' landscape: Sustainable land management for 'crisis' cities. GeoJournal 2018, 1-19. [CrossRef]

65. Tanrivermis, H. Agricultural land-use change and sustainable use of land resources in the Mediterranean region of Turkey. J. Arid Environ. 2003, 54, 553-564. [CrossRef]

66. Moisides, A. Rural Society in Modern Greece, 1950-1980; Mediterranean Studies Foundation: Athens, Greece, 1986. (In Greek)

67. Grove, A.T.; Rackham, O. The Nature of Mediterranean Europe: An Ecological History; Yale University Press: New Haven, CT, USA, 2001.

68. Bakker, M.M.; Govers, G.; Kosmas, C.; van Vanacker, V.; Oost, K.; Rounsevell, M. Soil erosion as a driver of land-use change. Agric. Ecosyst. Environ. 2005, 105, 467-481. [CrossRef]

69. Iosifides, T.; Politidis, T. Socio-economic dynamics, local development and desertification in WesternLesvos, Greece. Local Environ. 2005, 10, 487-499. [CrossRef]

70. Kizos, T.; Plieninger, T.; Schaich, H. Instead of 40 sheep there are 400: Traditional grazing practices and landscape change in Western Lesvos, Greece. Landsc. Res. 2005, 38, 476-498. [CrossRef]

71. Mancino, G.; Nolè, A.; Salvati, L.; Ferrara, A. In-between forest expansion and cropland decline: A revised USLE model for soil erosion risk under land-use change in a Mediterranean region. Ecol. Indic. 2016, 71, 544-550. [CrossRef]

72. Zalidis, G.; Stamatiadis, S.; Takavakoglou, V.; Eskridge, K.; Misopolinos, N. Impacts of agricultural practices on soil and water quality in the Mediterranean region and proposed assessment methodology. Agric. Ecosyst. Environ. 2002, 88, 137-146. [CrossRef]

73. Plieninger, T.; Rolo, V.; Moreno, G. Large-scale patterns of Quercus ilex, Quercus suber, and Quercus pyrenaica, regeneration in Central-Western Spain. Ecosystems 2010, 13, 644-660. [CrossRef]

74. Kairis, O.; Karavitis, C.; Kounalaki, A.; Fasouli, V.; Salvati, L.; Kosmas, K. The effect of land management practices on soil erosion and land desertification in an olive grove. Soil Use Manag. 2013, 29, 597-606. [CrossRef] 
75. Karamesouti, M.; Detsis, V.; Kounalaki, A.; Vasiliou, P.; Salvati, L.; Kosmas, C. Land-use and land degradation processes affecting soil resources: Evidence from a traditional Mediterranean cropland (Greece). Catena 2015, 132, 45-55. [CrossRef]

76. Pisinaras, V.; Tsihrintzis, VA.; Petalas, C.; Ouzounis, K. Soil salinisation in the agricultural lands of Rhodope District, northeastern Greece. Environ. Monit. Assess. 2010, 16, 79-94. [CrossRef] [PubMed]

77. Barbayiannis, N.; Panayotopoulos, K.; Psaltopoulos, D.; Skuras, D. The influence of policy on soil conservation: A case study from Greece. Land Degrad. Dev. 2011, 22, 47-57. [CrossRef]

78. Kosmas, C.; Danalatos, N.; Kosma, D.; Kosmopoulou, P. Greece. In Soil Erosion in Europe; Boardman, J., Poesen, J., Eds.; John Wiley and Sons: Chichester, UK, 2006; pp. 279-288.

79. Ragkos, A.; Samathrakis, V.; Theodoridis, A.; Notta, O.; Batzios, C.; Tsourapas, E. Specialization and Concentration of Agricultural Production in the Region of Central Macedonia (Greece). In Proceedings of the 7th International Conference on Information and Communication Technologies in Agriculture, Food and Environment (HAICTA 2015), Kavala, Greece, 17-20 September 2015.

80. Ioannides, D.; Apostolopoulos, Y.; Sönmez, S.F. Mediterranean Islands and Sustainable Tourism Development: Practices, Management and Policies; Continuum: London, UK, 2001.

81. Castro, H.; Barrico, L.; Rodríguez-Echeverría, S.; Freitas, H. Trends in plant and soil microbial diversity associated with Mediterranean extensive cereal-fallow rotation agro-ecosystems. Agric. Ecosyst. Environ. 2018, 217, 33-40. [CrossRef]

82. Levers, C.; Müller, D.; Erb, K.; Haberl, H.; Jepsen, M.R.; Metzger, M.J.; Verburg, P.H. Archetypical patterns and trajectories of land systems in Europe. Reg. Environ. Chang. 2018, 18, 715-732. [CrossRef]

83. Estel, S.; Kuemmerle, T.; Alcantara, C.; Levers, C.; Prishchepov, A.; Hostert, P. Mapping farmland abandonment and recultivation across Europe using MODIS NDVI time series. Remote Sens. Environ. 2015, 163, 312-325. [CrossRef]

84. Boellstorff, D.; Benito, G. Impacts of set-aside policy on the risk of soil erosion in central Spain. Agric. Ecosyst. Environ. 2005, 107, 231-243. [CrossRef]

85. Huusela-Veistola, E.; Alanen, E.L.; Hyvönen, T.; Kuussaari, M. Ecosystem service provision by establishing temporal habitats in agricultural environments. In Proceedings of the Conference: NJF Seminar 436: Biodiversity in Agriculture-Lessons Learned and Future, Hardanger, Norway, 24-26 May 2011.

86. Robleño, I.; Bota, G.; Giralt, D.; Recasens, J. Fallow management for steppe bird conservation: The impact of cultural practices on vegetation structure and food resources. Biodivers. Conserv. 2017, 26, 133-150. [CrossRef]

87. Salvati, L.; Zitti, M.; Ceccarelli, T. Integrating economic and environmental indicators in the assessment of desertification risk: A case study. Appl. Ecol. Environ. Res. 2008, 6, 129-138. [CrossRef]

88. Schaich, H.; Kizos, T.; Schneider, S.; Plieninger, T. Land change in eastern Mediterranean wood-pasture landscapes: The case of deciduous oak woodlands in Lesvos (Greece). Environ. Manag. 2015, 56, 110-126. [CrossRef] [PubMed]

89. Tscharntke, T.; Batáry, P.; Dormann, C.F. Set-aside management: How do succession, sowing patterns and landscape context affect biodiversity? Agric. Ecosyst. Environ. 2011, 143, 37-44. [CrossRef]

90. Salvati, L. Urban expansion and high-quality soil consumption-An inevitable spiral? Cities 2013, 31, 349-356. [CrossRef]

91. Salvati, L. The Dark Side of the Crisis: Disparities in per Capita income (2000-2012) and the Urban-Rural Gradient in Greece. Tijdschr. Econ. Soc. Geogr. 2016, 107, 628-641. [CrossRef]

92. Tzanopoulos, J.; Mitchley, J.; Pantis, J.D. Vegetation dynamics in abandoned crop fields on a Mediterranean island: Development of succession model and estimation of disturbance thresholds. Agric. Ecosyst. Environ. 2007, 120, 370-376. [CrossRef]

93. Kizos, T.; Dalaka, A.; Petanidou, T. Farmers' attitudes and landscape change: Evidence from the abandonment of terraced cultivations on Lesvos, Greece. Agric. Hum. Values 2010, 27, 199-212. [CrossRef]

94. Rontos, K.; Grigoriadis, S.; Sateriano, A.; Syrmali, M.; Vavouras, I.; Salvati, L. Lost in Protest, Found in Segregation: Divided Cities in the Light of the 2015 'Oki' Referendum in Greece. City Cult. Soc. 2016, 7, 139-148. [CrossRef]

95. Komnitsas, K.A.; Doula, M.K. Framework to improve sustainability of agriculture in small islands: The case of Pistacia vera L. cultivation in Aegina, Greece. Environ. Forensics 2017, 18, 214-225. [CrossRef]

96. AgroStrat. Sustainable Strategies for the Improvement of Seriously Degraded Agricultural Areas: The Example of Pistachia vera L. Available online: http:/ / www.agrostrat.gr/ (accessed on 10 January2017). 
97. Bartzas, G.; Komnitsas, K. Life cycle analysis of pistachio production in Greece. Sci. Total Environ. 2017, 595, 13-24. [CrossRef] [PubMed]

98. Duvernoy, I.; Zambon, I.; Sateriano, A.; Salvati, L. Pictures from the Other Side of the Fringe: Urban Growth and Peri-urban Agriculture in a Post-industrial City (Toulouse, France). J. Rural Stud. 2018, 57, $25-35$. [CrossRef]

99. Perrin, C.; Nougarèdes, B.; Sini, L.; Branduini, P.; Salvati, L. Governance changes in peri-urban farmland protection following decentralisation: A comparison between Montpellier (France) and Rome (Italy). Land Use Policy 2018, 70, 535-546. [CrossRef]

100. Serra, P.; Saurì, D.; Salvati, L. Peri-urban agriculture in Barcelona: Outlining landscape dynamics vis à vis socio-environmental functions. Landsc. Res. 2017. [CrossRef]

101. Vogiatzakis, G.; Pungetti, A.M. (Eds.) Mediterranean Island Landscapes: Natural and Cultural Approaches; Landscape Series, 9; Springer Publishing: Berlin, Germany, 2008; pp. 101-114.

102. Cardador, L.; De Cáceres, M.; Bota, G.; Giralt, D.; Casas, F.; Arroyo, B.; Brotons, L. A resource-based modelling framework to assess habitat suitability for steppe birds in semiarid Mediterranean agricultural systems. PLoS ONE 2014, 9, e92790. [CrossRef] [PubMed]

103. Colantoni, A.; Mavrakis, A.; Sorgi, T.; Salvati, L. Towards a 'polycentric' landscape? Reconnecting fragments into an integrated network of coastal forests in Rome. Rend. Lincei 2015, 26, 615-624. [CrossRef]

104. Zitti, M.; Ferrara, C.; Perini, L.; Carlucci, M.; Salvati, L. Long-term Urban Growth and Land-use Efficiency in Southern Europe: Implications for Sustainable Land Management. Sustainability 2015, 7, 3359-3385. [CrossRef]

105. Alphan, H. Land-use change and urbanisation of Adana, Turkey. Land Degrad. Dev. 2003, 14, 575-586. [CrossRef]

106. Marull, J.; Mallarach, J.M. A GIS methodology for assessing ecological connectivity: Application to Barcelona Metropolitan Area. Landsc. Urban Plan. 2005, 71, 243-262. [CrossRef]

107. Paul, V.; Tonts, M. Containing urban sprawl: Trends in land-use and spatial planning in the Metropolitan Region of Barcelona. J. Environ. Plan. Manag. 2005, 48, 7-35. [CrossRef]

108. Detsis, V.; Ntasiopoulou, G.; Chalkias, C.; Efthimiou, G. Recent Insular Mediterranean Landscape Evolution: A Case Study on Syros, Greece. Landsc. Res. 2010, 35, 361-381.

109. Cuadrado-Ciuraneta, S.; Durà-Guimerà, A.; Salvati, L. Not only tourism: Unravelling suburbanization, second-home expansion and "rural" sprawl in Catalonia, Spain. Urban Geogr. 2017, 38, 66-89. [CrossRef]

110. Sallustio, L.; Pettenella, D.; Merlini, P.; Romano, R.; Salvati, L.; Marchetti, M.; Corona, P. Assessing the economic marginality of agricultural lands in Italy to support land use planning. Land Use Policy 2018. [CrossRef]

111. Kasanko, M.; Barredo, J.I.; Lavalle, C.; McCormick, N.; Demicheli, L.; Sagris, V.; Brezger, A. Are European Cities Becoming Dispersed? A Comparative Analysis of Fifteen European Urban Areas. Landsc. Urban Plan. 2006, 77, 111-130. [CrossRef]

112. Zambon, I.; Colantoni, A.; Cecchini, M.; Mosconi, E.M. Rethinking sustainability within the viticulture realities integrating economy, landscape and energy. Sustainability 2018, 10, 320. [CrossRef]

113. Mosconi, E.M. Opportunity and function of energy wholesale market in Italy. Rivista Giuridica dell'ambiente 2003, 18, 1101-1110.

114. Biasi, R.; Brunori, E.; Ferrara, C.; Salvati, L. Towards sustainable rural landscapes? A multivariate analysis of the structure of traditional tree cropping systems along a human pressure gradient in a Mediterranean region. Agrofor. Syst. 2017, 91, 1199-1217. [CrossRef]

115. Feranec, J.; Jaffrain, G.; Soukup, T.; Hazeu, G. Determining changes and flows in European landscapes 1990-2000 using CORINE land cover data. Appl. Geogr. 2010, 30, 19-35. [CrossRef]

(C) 2018 by the authors. Licensee MDPI, Basel, Switzerland. This article is an open access article distributed under the terms and conditions of the Creative Commons Attribution (CC BY) license (http://creativecommons.org/licenses/by/4.0/). 